\title{
Heat Treatment Optimizing of MgZnZr Alloy
}

\author{
Haijuan Kang \\ HNKJDX
}

School of Materials Science and Engineering, He nan University of Science and Technology Luoyang 471023, China kanghaijuan03@126.com

\author{
Quan-an Li \\ HNKJDX \\ School of Materials Science and \\ Engineering, He nan University of \\ Science and Technology \\ Luoyang 471023 , China
}

\author{
Wei Zhou \\ HNKJDX \\ School of Materials Science and \\ Engineering, He nan University of \\ Science and Technology \\ Luoyang 471023, China
}

\begin{abstract}
The effects of heat treatment on microstructures and mechanical properties of MgZnZr alloy have been investigated through the preparation of alloy, analysis of microstructure and test of mechanical properties. The results show that, the microstructures and mechanical properties of $\mathrm{Mg}-5.5 \% \mathrm{Zn}$ $0.5 \% \mathrm{Zr}$ alloy can be improved by solid solution $\left(380^{\circ} \mathrm{C} \times 12 \mathrm{~h}\right)$ and aging $\left(190{ }^{\circ} \mathrm{C} \times 12 \mathrm{~h}\right)$ treatment. Compared with solid solution, direct aging treatment can be operated easily and optimize the heat-treatment process of MgZnZr alloy.
\end{abstract}

\section{Keywords-MgZnZr alloy; heat treatment; optimizing}

\section{INTRODUCTION}

Magnesium alloy is the lightest of all the metallic materials. Magnesium alloy has advantages of high specific strength and rigidity, excellent damping effect, and thermal conductivity, so it is widely used in lots of fields, such as space flight, automobile manufacturing, electron industry, and 3C products[1 5]. MgZnZr alloy have much higher specific strength and corrosion resistance, so how to improve it's microstructures and mechanical properties has being studied at present. Excellent Strengthen effect can be obtained by aging treatment for $\mathrm{MgZnZr}$ alloy [6 8]. The effects of heat treatment on microstructures and mechanical properties and how to optimize the heat-treatment process of $\mathrm{MgZnZr}$ alloy have been investigated in this paper.

\section{EXPERIMENTAL}

Raw materials are metallic magnesium (purity 99.95 wt.\% ), metallic zinc (purity 99.98wt.\%) and $\mathrm{Mg}-30 \% \mathrm{Zr}$ master alloys. All the raw materials should be baked before melted. The chemical composition of the experimental alloys are designed as $\mathrm{Mg}-5.5 \% \mathrm{Zn}-0.5 \% \mathrm{Zr}$. The alloys were melted in an induction furnace under the protection atmosphere of the combination gas of $\mathrm{SF}_{6}$ and $\mathrm{CO}_{2}$. When the liquid alloy was heated to $680^{\circ} \mathrm{C}$, it was poured into a metallic mold which preheated at $150^{\circ} \mathrm{C}$, and then the specimens were obtained. The specimens were heat treated divided into two parts, one part were heat treated for solid solution at $380^{\circ} \mathrm{C}$ for $12 \mathrm{~h}$ and aged at $190^{\circ} \mathrm{C}$ for $12 \mathrm{~h}$ covered with $\mathrm{MgO}$ powders, another part were direct aging treatment at $170^{\circ} \mathrm{C}, 190^{\circ} \mathrm{C}$ and $210^{\circ} \mathrm{C}$, for $4 \mathrm{~h}, 8 \mathrm{~h}, 12 \mathrm{~h}, 16 \mathrm{~h}, 20 \mathrm{~h}, 24 \mathrm{~h}$ and $28 \mathrm{~h}$.

The tensile experiment was conducted on AG-I250kN precise universal test machine, with the rate of $1 \mathrm{~mm}$ a minute. The hardness of alloy was studied on Vivtorinox hardness meter. The microstructure of alloy was observed by an Olympus optical microscope. The fracture morphologies were observed and analyzed by SEM (JSM-5610LV).

\section{RESULTS AND DISCUSSION}

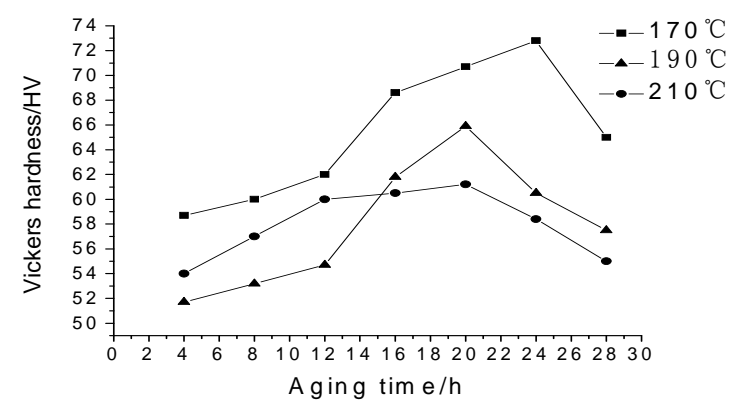

Fig. 1 The hardness of alloy with different aging treatment

Fig. 1 shows the hardness of alloy with different aging treatment. It can be seen that, the hardness of cast alloy is $52.3 \mathrm{HV}$, which is $72.9 \mathrm{HV}$ for solid solution and aging treatment alloy. Compared with $190{ }^{\circ} \mathrm{C}$ and $210{ }^{\circ} \mathrm{C}$, the hardness of aging alloy is higher at $170^{\circ} \mathrm{C}$ and increase with the aging time. The hardness of aging alloy for $24 \mathrm{~h}$ at $170^{\circ} \mathrm{C}$ is up to maximums $72.8 \mathrm{HV}$. Higher hardness can be get by direct aging for MgZnZr alloy.

TABLE I. THE RESULT OF TENSILE EXPERIMENT

\begin{tabular}{|c|c|c|c|c|}
\hline \multirow{2}{*}{$\begin{array}{c}\text { Heat treatment } \\
\text { alloy }\end{array}$} & \multicolumn{2}{|c|}{$25^{\circ} \mathrm{C}$} & \multicolumn{2}{c|}{$1500^{\circ} \mathrm{C}$} \\
\cline { 2 - 5 } & $\sigma b(\mathrm{MPa})$ & $\delta(\%)$ & $\begin{array}{c}\sigma \\
b(\mathrm{MPa})\end{array}$ & $\delta(\%)$ \\
\hline cast & 159.2 & 6.93 & & \\
\hline $\begin{array}{c}\text { solid solution and } \\
\text { aging }\end{array}$ & 205.5 & 5.02 & 195.2 & 8.43 \\
\hline aging 24h at $170{ }^{\circ} \mathrm{C}$ & 221.2 & 6.66 & 200.9 & 8.91 \\
\hline
\end{tabular}

Table 1 shows the results of tensile strength and elongation of the alloy after different heat-treatment. At room temperature, the tensile strength of the cast is only159.2Mpa. After solid solution and aging or direct aging, the tensile strength increase obviously, they are up to $205.5 \mathrm{Mpa}$ and $221.2 \mathrm{Mpa}$ at room temperature and $150{ }^{\circ} \mathrm{C}$ respectly. We can see that, compared with solid solution and aging, the tensile strength and elongation of the direct aging alloy are better. So the mechanical properties of $\mathrm{Mg}-5.5 \% \mathrm{Zn}-0.5 \% \mathrm{Zr}$ alloy can be 
improved by aging treatment. Compared with solid solution, direct aging treatment can be operated easily and optimize the heat-treatment process of $\mathrm{MgZnZr}$ alloy.

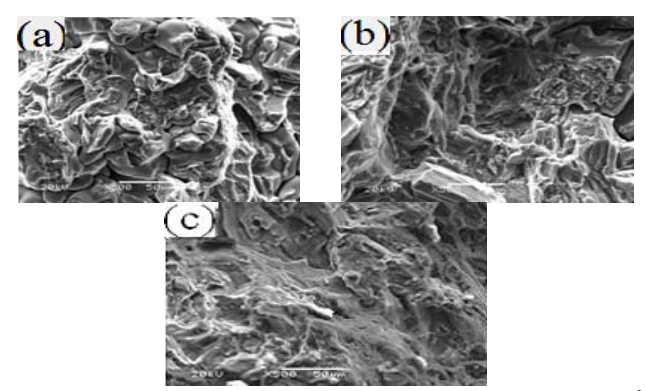

(a) cast (b) solid solution and aging (c) aging $24 \mathrm{~h}$ at $170^{\circ} \mathrm{C}$

Fig. 2 The fracture morphologies of $\mathrm{Mg}-5.5 \mathrm{Zn}-0.5 \mathrm{Zr}$ alloy after different heat-treatment

Fig. 2 shows the fracture morphologies of $\mathrm{Mg}-5.5 \mathrm{Zn}-0.5 \mathrm{Zr}$ alloy after different heat-treatment. The fracture morphologies of cast alloy has lots of inward depression facets, where many bend tear ridges exist. This shows features of quasi cleavage belong to brittle fracture. The fracture morphologies of solid solution and aging alloy has some tear ridges and dimples. There are a few inclusions in the middle of dimples and this fracture shows ductile fracture feature. The fracture morphologies of aging $24 \mathrm{~h}$ at $170{ }^{\circ} \mathrm{C}$ alloy shows brittle fracture feature, which performance for the river pattern, quasi cleavage steps and smooth fracture surface can be seen. When the aging time extend to $24 \mathrm{~h}$, There are some tear ridges and dimples and inclusions in the middle of dimples, which shows ductile fracture.

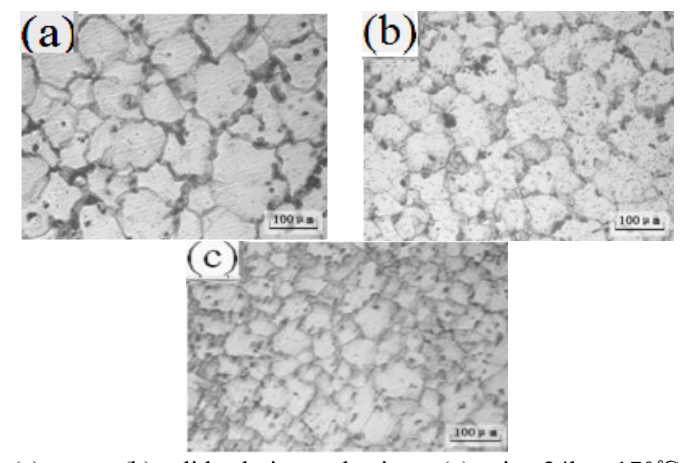

(a) cast (b) solid solution and aging (c) aging $24 \mathrm{~h}$ at $170^{\circ} \mathrm{C}$

Fig. 3 The microstructures of Mg-5.5Zn-0.5Zr alloy after different heattreatment

Fig. 3 shows the microstructures of $\mathrm{Mg}-5.5 \mathrm{Zn}-0.5 \mathrm{Zr}$ alloy after different heat-treatment. It can be seen that, the microstructure of cast alloy is mainly constituted of $\alpha-\mathrm{Mg}$ matrix, grain boundaries and continuous reticular eutectic structure. $\alpha-\mathrm{Mg}$ matrix is gray white, the phenomenon of dendritic crystal is serious, eutectic structure is uneven. There are many eutectic products and the second phases exist along the grain and dendritic crystal boundaries.

The crystal grain size of solid solution and aging alloy is better. A large number tiny fine needle precipitated phase can be seen in the crystal and boundaries. The crystal boundary microstructures of alloy change a little, but most of unbalance eutectic structures disappear. Therefore the boundary thickness of solid solution and aging alloy is smaller than the cast.

What can be seen from the microstructure of direct aging alloy is that, part of unbalance eutectic structures on boundaries disappear and very tiny alloy compounds precipitated phase appear in the crystals, reticular boundaries become coarsening and clear. Because the energy of crystal boundaries is higher $[9,10]$, meanwhile with the increase time of aging, precipitated phases increase and new phases nucleate along crystal boundary and grow toward crystal, all these cause boundaries become coarsening and clear as well as the crystal grains size of the alloy is remarkably refined, improve the comprehensive properties of alloy extremely.

\section{CONCLUSIONS}

(1) Solid solution $\left(380^{\circ} \mathrm{C} \times 12 \mathrm{~h}\right)$ and $\operatorname{aging}\left(190^{\circ} \mathrm{C} \times 12 \mathrm{~h}\right)$ treatment or direct aging $\left(170^{\circ} \mathrm{C} \times 24 \mathrm{~h}\right)$ treatment can improve the microstructures of $\mathrm{Mg}-5.5 \% \mathrm{Zn}-0.5 \% \mathrm{Zr}$ alloy, and promote its mechanical properties.

(2) After Solid solution $\left(380^{\circ} \mathrm{C} \times 12 \mathrm{~h}\right)$ and aging $\left(190^{\circ} \mathrm{C} \times\right.$ $12 \mathrm{~h})$ treatment, the values of tensile strength of the alloy at room temperature and $150^{\circ} \mathrm{C}$ are up to $205 \mathrm{MPa}$ and $195.2 \mathrm{MPa}$ respectively. After direct aging $\left(170{ }^{\circ} \mathrm{C} \times 24 \mathrm{~h}\right)$ treatment, the values of tensile strength of the alloy at room temperature and $150^{\circ} \mathrm{C}$ improve relatively, up to $221.2 \mathrm{Mpa}$ and $200.9 \mathrm{MPa}$ respectively.

(3) Compared with solid solution, direct aging $\left(170^{\circ} \mathrm{C} \times 24 \mathrm{~h}\right)$ treatment can optimize the heat-treatment process of $\mathrm{Mg}$ $5.5 \mathrm{Zn}-0.5 \mathrm{Zr}$ alloy.

\section{REFERENCES}

[1] J.Z.Zhang,Z.X.Ma,D.F.Li, et al. The effects of heat treatment on microstructures and mechanical properties of Mg-Gd-Y-Zr alloy. Hot working technology, Vol. 36(2007), p.73 (in chinese)

[2] L.A. Dobrza'nski, T. Tanski, L.Cizek. Structure and properties of magnesium cast alloys. Journal of Materials Processing Technology, Vol.192-193 (2007), p.567

[3] H.M.Wang, Z.H.Chen, H.G.Yan, et al. Heat treatment of magnesium alloy. Heat treatment of metals ,Vol. 30(2008), p. 49 (in chinese)

[4] Y. Fan, G.H. Wu, H.T. Gao, et al. Foundry Engineering Technology, Vol. 25(2004), p.941(in chinese)

[5] L.Q. Zhu, G.L. Song. Surface and Coating Technology, Vol. 200(2006), p.2834 (in chinese)

[6] G. L. Makar, J. Kruger. Journal of the Electrochemical Society, Vol.137( 1990), p. 414(in chinese)

[7] J. F. Nie, X. Gao, S. M. Zhu. Enhanced age hardening response and creep resistance of $\mathrm{Mg}-\mathrm{Gd}$ alloys containing $\mathrm{Zn}$. Scripta Materialia, Vol.53(2005), p. 1049. (in chinese)

[8] X.Q.Chen, J.W.Liu, C.P.Luo. Research status and development trend of high strength Mg-Zn alloy[J]. Materials review, Vol. 22(2008), p.58 (in chinese)

[9] Petukhov B V. A mechanism of strong solid-solution hardening of intermetallics within the range of anomalous temperature behavior of the yield stress. Materials Science and Engineering A, Vol.483( 2008), p. 492.

[10] Per Bakke, Hakon, Westengen. Die casting for high performance focus on alloy development.Advanced Engineering Materials, Vol.12( 2003), p. 879 